\title{
Research and Practice of College English Teaching Model Reform Based on Information
}

\author{
Xin Yang \\ English Department, Heze Medical College, Heze 274000, China. \\ young0912@163.com
}

Keywords: Information, College English, Teaching model, Topic.

\begin{abstract}
The application of modern information technology in college English teaching plays an important role in improving the way of learning and teaching methods. It not only changes the traditional college English teaching model, but also becomes an effective strategy to improve college English teaching. There is still the problem of low efficiency and insufficient application. However, the reform of university-based teaching model based on information technology can effectively improve the key to college English teaching. This article discusses the significance of education information in college English teaching practice, the problems in college English teaching in the process of education information, and several effective strategies to help improve college English teaching practice.
\end{abstract}

\section{Introduction}

The English listening and speaking ability of Chinese college students is low. It is typical that the scores of listening are low in various examinations, and the phenomenon of inadequacies in English oral communication often occurs. The reasons are mainly the following four aspects. First, in the process of audio-visual-speaking teaching, teachers do not make full use of modern information technology and cannot visualize, diversify, visualize, and improve the abstract elements in audio-visual-sounding teaching. Second, teachers are mainly imparting knowledge, students are passively involved in listening and speaking, and thirdly, listening and oral training are inconsistent in class, and they do not achieve the integrated training of "visual, listening, and speaking" in the true sense. Fourth, poor student self-learning ability after class. The teaching effect did not reach the expected goal. Therefore, exploring a new teaching model in College English audio-visual teaching has become an important issue in current teaching reform [1].

\section{Instructive Significance of Education Information to College English Teaching Practice}

\subsection{Education Information Makes College English Teaching}

By changing the way of learning more flexible and diverse the wide application of information technology in college English teaching will inevitably have a profound impact on the teaching process. New media and new technologies provide the conditions and basis for enriching teaching methods. Teachers have more choices and richer creative space in the teaching process [2].

\subsection{Educational Information Changes Traditional College English Teaching Model}

The traditional college English teaching model is characterized by classroom teaching, emphasizing students' understanding and students working alone; teachers are omniscient; the contents of teaching are old and the unity of culture. This kind of indoctrination teaching has greatly limited learners' autonomous learning and has been unable to adapt to the rapid development of information technology and the concept of new education. In practice, education Information can replace teachers' lectures in the form of teachers instead of teacher-board books, and electronic textbooks can be used instead of printed textbooks to achieve online learning [3]. In addition, the establishment of the Internet platform under the support of information technology enables every learner to learn in accordance with his own methods, making autonomous learning inevitable. 


\subsection{Education Information Builds a Good New Relationship between Learning and Teaching}

Under the impact of information technology, teachers' duties are no longer focused solely on knowledge indoctrination, but rather on the development of polarization, and play a role in the navigation of knowledge, behavior, and emotional communication. The modern teaching information network has provided us with rich and varied teaching information. Teachers should rely on their own experience and macroscopic grasp of English knowledge, change some of the contents of traditional textbooks according to the needs of the curriculum, and use modern educational information technology to design and develop in accordance with the times. Demand for teaching resources, re-organizing the teaching style and teaching strategies of college English courses.

\section{Improve the Specific Strategies of College English Teaching Information}

\subsection{Optimization of "Hardware and Software" Facility Construction First of All, Hardware Construction.}

Desktop computers, projectors, electronic screens, video disc players, video recorders, microphones, and speakers form the basic equipment system for multimedia classrooms in ordinary colleges and universities. In addition to a large amount of capital investment, there are constant technological updates and improvements. Therefore, at the same time when these infrastructures are equipped, schools must also pay attention to the regular maintenance, inspection, updating, and improvement of hardware equipment, so as to avoid the confidence of teachers in the use of information technology due to frequent occurrence of hardware equipment. Followed by software construction. If you say that the hardware device is a watch, then the software facility is in, and there is no place to be too empty. Wei Ling believes that the construction of multimedia English teaching software should emphasize the five principles of adaptability, interest, motivation, interactivity, and gradualness. The production of effective teaching software is by no means accomplished by a single force. It is designed, developed, and produced by divisions of labor, teachers, education experts, and software developers. Front-line teachers are responsible for the sorting and selection of materials and information sources, educational experts responsible for auditing, designing information content metrics and arrangements, and software developers are responsible for using technological means to optimize resources as much as possible to achieve the desired vision [4].

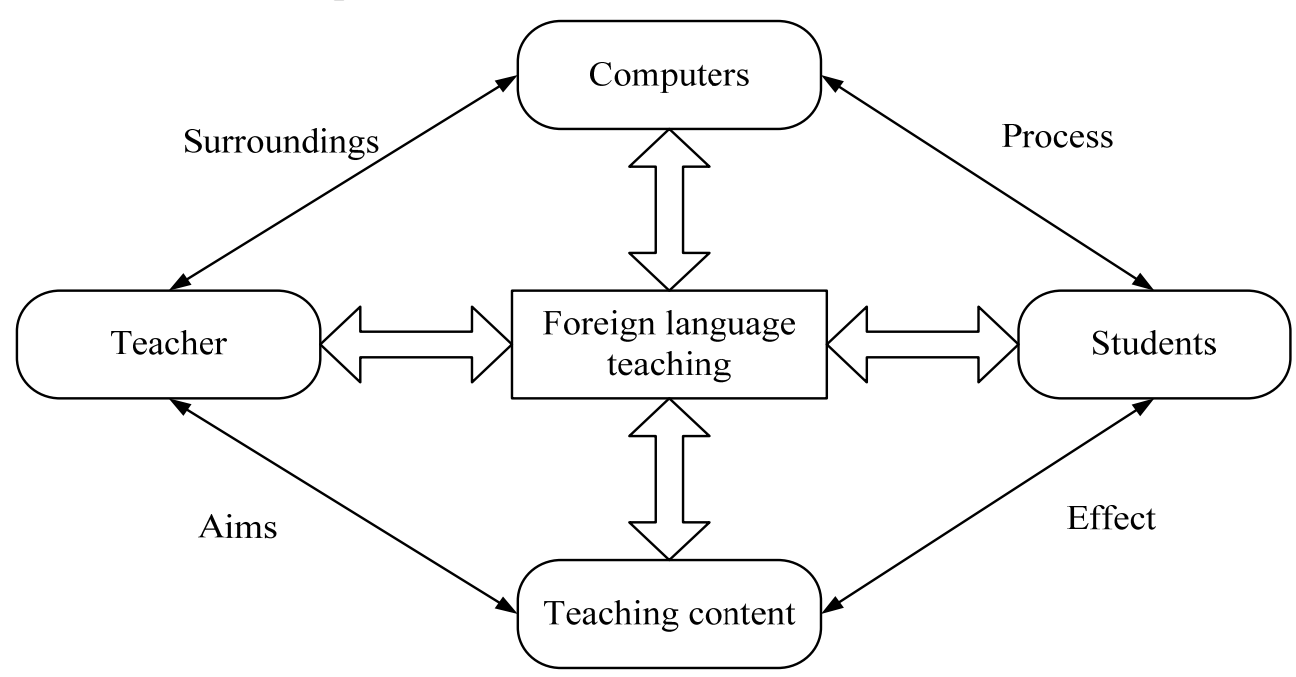

Fig 1. The Framework of Informational Computer Foreign Language Teaching

\subsection{Strengthening the Construction of English Teaching Courses}

Improve teachers and students' understanding of the "dual-master" teaching model the "dual-master" model is a two-way teacher's leading role and a student's main cognitive role. It is the essence of "teacher-centered" and "student-centered". Discard its dross, neither of which can be thin. The "pass-accept" teaching approach is integrated with human-computer interaction and human interaction. It not only gives full play to the leading role of the teacher, but also gives the student more opportunities to learn and accumulate self-discovery, self-discovery, self-monitoring and 
self-analysis. self-thinking ability and experience, so as to form a new type of stable teaching mode [5].

\subsection{Teacher Information is Mainly Reflected in the Role of}

(1) Teachers need to experience how to use the advantages of computers to acquire new knowledge. (2) In addition to basic ones, for example, skilled palm, matching, and search. Teachers use the Internet to teach, answer questions, and view life experiences to experience problems and frustrations students may encounter in learning activities in order to guide students more effectively. Computer operations and applications, teachers also need to have a certain degree of understanding of the basic functions of the computer such as the database function how to "classify the data grouping" in the database, to lay the technical foundation for their own post-return work (3) Diligence Network teaching platform management. The interactive functions of the learning system are kept in touch with the students at all times such as laying out task records, reviewing assignments, and querying progress. (4) To formulate and strictly implement appropriate online learning regulations. If teachers formulate rules and regulations concerning self-directed learning, regularly administer online, carefully punish rewards and punishments, and maintain interaction with students, the awareness and ability of students' independent learning will gradually strengthen, and teaching effectiveness will increase. The main body of student information is embodied in learning methods. The most important thing in the effective integration and interaction of information technology and English courses is to encourage students to actively recognize and actively construct.

\subsection{Students Must Invest in the Learning Environment}

With teams as a unit, knowledge is applied to practice through cooperation and discussion. Second, students should assume the role of explorer and researcher. The teaching structure of integration of information technology and college English not only requires students to learn knowledge information, but also requires students to proceed from problems and tasks, use some information technology to inquire and research solutions, and build meaningful knowledge. Students must also have the appropriate technical skills. Proficient in computer technology tools such as word documents, Excel spreadsheets, PPT presentations, web search, emails, and databases.

Improve the information literacy of teachers and students as mentioned above, the dominant role of teachers and the main roles of students must be based on certain technical capabilities and information literacy, so as to better realize the dual-teacher model of college English in the information age. Really promote the effective implementation of the dual-master teaching mode. Improve teachers' information technology capabilities and theoretical literacy.

\subsection{Strengthen Information Technology Training for English Teachers}

Arrange for a fixed period of time, through online training, software training, practical training, etc., to help teachers master practical methods such as the use of online teaching platform to construct curriculum systems, specific operating procedures and management measures, use of modern information technologies and interactive platforms such as Internet, Geometry Sketchpad, Concept Map, PowerPoint, Frontpage, Camtasia, Crazy Talk, and other related software tools are used to create micro-curricula, mottles, micro-classrooms, and various courseware. In the process, teachers gradually increase their access to information and processing capabilities. The ability to organize, communicate, and research improves its self-confidence in using information technology for teaching, making it "be able to act and dare".

Scientifically and reasonably formulate incentive policies for information-based teaching. Such as encouraging teachers to participate in all levels of information-based English teaching contest and give a certain material rewards and honor recognition; recognize and reward teachers for online teaching and enhance the majority of British teachers to discuss and discuss this teaching mode network management and network interaction the workload. The teacher of language learns the initiative and enthusiasm of using information technology and applying it to everyday teaching.

After associating modern English education concepts and training for college English teachers, the teaching methods used by teachers in teaching demonstrations and teaching videos were analyzed through the organization of excellent teachers' informational teaching demonstrations, video learning, and guides, and teachers were asked to specify The theoretical background and the theoretical 
connotation force the teachers to independently inquire and master relevant theoretical knowledge so as to improve the teachers' theoretical accomplishment. Improve students' information technology skills and ideological cultivation. Specializes in related information technology training courses, teaches students some of the most practical network technologies, teaches students the ability to use information technology to search, select, analyze, and summarize required information, and trains students on how to conduct online self-learning, and in relevant classrooms. Strengthen the practice of technology to help students master the specific operation steps and precautions so as to "know what they are" so that they can use information technology to effectively complete the course learning task. Emphasizing the importance of mastering information technology for autonomous learning on the Internet, guiding students to participate voluntarily and making them "learn what is happening", guiding students to use the Internet correctly, consciously resisting the poisoning of unhealthy web pages, cultivating the right awareness of online information, and strengthening supervision and Management urges students to implement information-based learning behaviors and self-monitoring in an honest and efficient manner to improve students' information literacy.

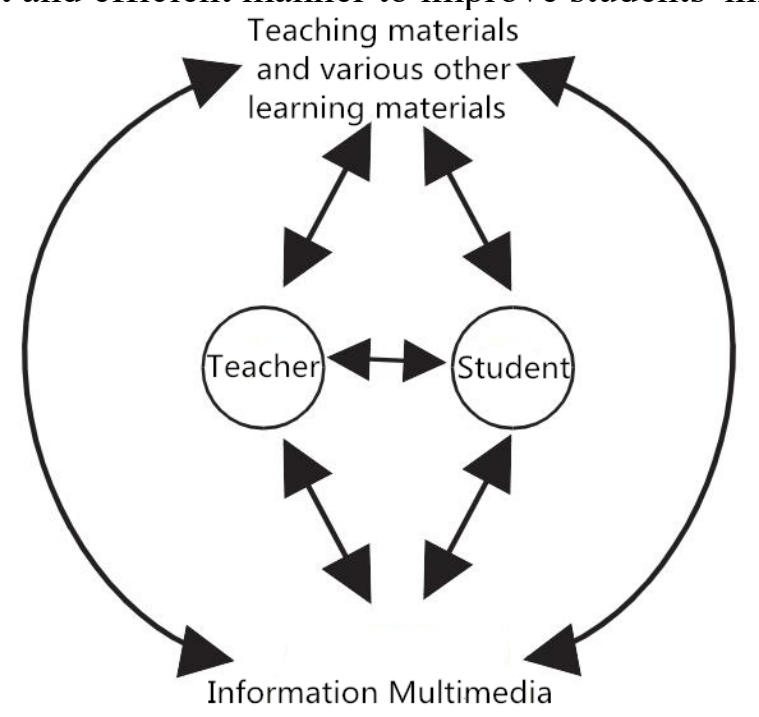

Fig 2. Multimedia information teaching materials

\section{Build Multidimensional and Interactive Information-Based Teaching Environment}

We must balance the internal environment of the multidimensional and interactive information-based English classroom. Such as inspecting and debugging in advance the optimization of information-based teaching equipment, according to the teaching content and teaching methods in advance allocation of student groups and seat layout, to provide material security for the Information classroom teaching; to build an equal and interactive teacher-student relationship, and strive to create a relaxed and harmonious learning Atmosphere, to provide emotional protection for information-based classroom teaching; to create inter-subject student and students, teams and groups and host-guest teacher-student and network, teaching content, environment classroom synergistic learning mechanism, to provide institutional protection for information-based classroom teaching Set up enlightening questions and encourage students to use the Internet to conduct inquiries and discuss solutions in the classroom, use the UMU platform for multidimensional online interaction, and provide interactive protection for informational classroom teaching. In short, college English teachers should create a positive and interactive information-based learning environment and a mufti-dimensional and interactive information-based English classroom internal environment, so as to promote the more efficient circulation of the various elements within the information-based college English classroom. We must actively create a multidimensional and interactive information-based English learning environment. Encourage students to use various online media models and platforms WeChat, QQ, Weibo, Baidu, etc. to explore knowledge, share learning experiences in English, discuss hot topics, and express feelings so as to realize the actual deep 
interaction of language, information network, and student life. Use school broadcasts to regularly broadcast English programs and guide students to participate in practical activities such as English style competitions, English film dubbing competitions, English media design competitions, English cultural promenades, etc. Organize to watch selected English movies, animations, even original entertainment programs, etc., To create a campus English interactive atmosphere and campus culture, so as to ensure the broadness and dimensional of information-based English learning.

\section{Teaching Management Departments Should Issue Relevant Teacher Management Methods.}

According to the teachers' time and energy invested in the use of the Internet for information-based teaching and management, certain teachers must be rewarded and punished. It is urged from the system that teachers must accept this new teaching model, so as to increase the enthusiasm of teachers to participate in information-based teaching reform. In the evaluation of teachers, whether "actively researching and developing online teaching" is used as an important indicator, and for positive performers to recognize certain achievements in the form of the system, and to respond to negative or no participation in network information-based teaching reforms. The teachers give some form of criticism and punishment. Teachers must introduce specific implementation methods for students' online learning. From the time limit, discipline requirements, rewards and punishment details, assessment ratios, etc., specific rules are formulated and strictly enforced to enhance students' importance and self-control of information-based teaching. Schools should establish effective and feasible quality monitoring systems. With the help of network system technology, teachers and students use the Internet for teaching and learning statistics and analysis to form a more comprehensive quality assessment model. The two-way supervision of teachers and students not only provides teachers with information to supervise students, facilitates teachers' adjustment of teaching strategies, but also provides schools with information on the advantages and disadvantages of teachers and students in the use of information technology for teaching and learning. To directly understand the development dynamics and practical effectiveness of teachers and students in the use of information technology.

\section{Conclusion}

The English listening and speaking ability of Chinese college students still cannot meet the needs of an internationalized society. As an important part of college English teaching, English speaking, listening and speaking is designed to better improve students' listening and speaking. According to the results of the course satisfaction survey, the audio-visual-speaking course has generally been recognized by many students, but some problems have also been exposed in the teaching process. Combining with the common problems existing in colleges and universities, this article analyzes and sums up the current status of traditional audio-visual-sounding teaching, and proposes a multidimensional and three-dimensional visual, audio and listening teaching model. In the context of informational teaching is regarded as a comprehensive activity. Listening and speaking are organically integrated in all three aspects and are consistently applied throughout the teaching process. They make full use of the Internet platform and digital teaching resources to create a mufti-dimensional, three-dimensional learning environment for students; extend classroom teaching to depth and breadth; Teachers' classroom teaching is linked with students' self-learning and extracurricular activities, which makes learning move in the direction of individualization, autonomy, and innovation. This new teaching model can promote the balanced development of students' English input and output abilities, cultivate the college students' autonomous learning ability in English, and ultimately improve the comprehensive application ability of English. 


\section{References}

[1]. Department of Higher Education, et al. Ministry of Education. College English Teaching Requirements. Beijing: Higher Education Press, Vol. 6 (2007) No. 23, p.127-132.

[2]. Quan Lihong, et al. Network English audio-visual teaching constructivism design and evaluation. Electronic Language Teaching, Vol. 6 (2008) No. 23, p.221-228.

[3]. Deng Yingling, et al. The application of three-dimensional teaching mode under the network environment in the teaching of "English Viewing and Speaking" --- An analysis of "English Viewing and Speaking" national excellent course construction. Foreign Language and Foreign Language Teaching, Vol. 6 (2009) No. 23, p.315-318.

[4]. Deng Yingling, Bai Xiehong, et al. Research and Practice of English-based Viewing, Listening, and Speaking Cooperative Learning Strategies Based on Network. Foreign Language Teaching, Vol. 6 (2008) No. 23, p.132-136.

[5]. Zeng Qingmin, et al. College English Listening, Speaking, Listening and Speaking Trinity Teaching Model Study. Journal of Chongqing Jiaotong University Social Science Edition, Vol. 6 (2009) No. 23, p.339-345.

[6]. Zhuang Shujuan, et al. Multi-dimensional English listening and speaking teaching mode construction. Journal of Changchun Teachers College (Humanities and Social Sciences Edition, Vol. 6 (2013) No. 23, p.169-174. 